was appointed in November 1936 to consider the duties of excise chargeable under the Acts of 1802, 1804 and 1812, and any amendments thereto, and to report thereon and to make recommendations, and its report has now been issued (London: H.M. Stationery Office, 1937 ; price $3 d$. net). Complete abolition of these duties has been advocated, but the Committee recommends that the duties ought to continue and should apply to a wider field, and bring in a much larger revenue. At the same time, it recommends that the duty should be at the rate of twopence instead of threepence in the shilling, and should be graduated less steeply. The recommendations are of a far-reaching character, and bring in everything that looks like a drug or smells like one. As drafted, it would even seem that medicines prescribed or dispensed by medical practitioners are included, though it can scarcely be believed that this was intended. The Committee also sees no reason why the "modern chemist" should have "a very valuable preference" in the sale of preparations which claim the "known, admitted, and approved remedy" exemption which has hitherto enabled them to sell unstamped certain types of preparations liable to duty if sold by ordinary shopkeepers. Despite defects, the recommendations are on the whole in the interests of the public, and with certain amendments should prove acceptable.

\section{Acquisitions at the British Museum (Natural History)}

H.M. THE KING has presented to the Museum an exceptionally fine specimen of a black leopard from India. The skin is very dark and the spots are scarcely visible in certain lights. In March 1936, Mr. H. St. J. B. Philby set out on a journey through the districts of Asir and Najram in Arabia, returning to Jidda in the early part of this year. During this trip, Mr. Philby made large natural history collections which he has presented to the Museum. Apart from the birds which number 747 specimens belonging to some 100 species, the collections include mammals, reptiles, fishes, mollusca, a large number of insects, 230 botanical specimens, some minerals, and about 400 rocks. Among the birds, three are new to science, namely, a race of the common magpie, a small Scops owl, and an emerald cuckoo. His collection includes a number of eggs previously unknown. The Department of Entomology has received from Mrs. Tillyard a collection of 500 mayflies and 700 dragonflies which formed part of the late Dr. R. J. Tillyard's collection. Among the dragonflies are included the type specimens of 105 species, and among the mayflies of 8 species. This gift is perhaps the most valuable addition to the Museum collections in these groups that has been received for many years. Accessions to the Department of Geology include a collection of about 20,000 fossil invertebrates (including 60 type and figured specimens) from the Ordovician and Silurian strata of the Girvan district of Ayrshire. The collection was made by the late Mrs. Robert Gray of Edinburgh and her daughters. Mr. F. N. Ashcroft has presented a further series of 747 specimens from his collection of Swiss minerals.

\section{Repton School Science Society}

Ax the triennial conversazione of the Repton School Science Society on June 25 and 26, some forty demonstrations were shown. In the biology section, a way of recording the heart beat of a frog and the effect of stimulation by nerves, by electricity and by drugs, was shown and also a collection of local zoological and botanical specimens. Recent developments in chemical industry were illustrated by the moulding of bakelite cups in a home-made electricallyheated press producing a pressure of $1 \frac{1}{2}$ tons per sq. in., by the manufacture of rubber gloves from the latex by a simple dipping process using an experimental plant, and by electro-plating and bronzing on a semi-technical scale. A lecture was given in the physics section on electrical illumination, dealing with the development of lighting from the carbon filament lamp to the modern vapour discharge lamps. There were also demonstrations of a way of eliminating dazzle from motor-car headlights using the new polaroid screens and of a home-made model railway fitted with a system of automatic signalling and train control.

\section{Scientific and Industrial Research in Australia}

THE tenth annual report of the Council for Scientific and Industrial Research, Commonwealth of Australia, covers the year ended June 30,1936 , and in addition to reports on the five main divisions of the Council's work, refers to co-operation in research with New Zealand and to the meetings of the Standing Committee of Agriculture appointed as an advisory body to the Australian Council of Agriculture established in 1934 (Canberra : Government Printer, 1936. 4s.). Numerous reports to this Committee were furnished by the Council of Scientific and Industrial Research, dealing with such subjects as codling moth pest, survey of potato virus diseases, tobacco investigations, seed testing, weed pest investigations, soil drift, grasshopper investigations, etc. The Council also acts as a liaison with the Commonwealth Government on behalf of the Standards Association of Australia, and in this capacity provided reports on standardiza. tion of wearing parts of agricultural machinery, primary products, dusting sulphur, wire-netting and other galvanized products. During the year, the activities of the Council were extended to cover investigations into the problems of Australia's secondary industries, and a special committee has been set up to define the field and make recommendations regarding problems for investigation and the staff and organization required. A new Forest Products Laboratory approached completion during the year. This Division completed a full investigation of the veneer and plywood industry in Queensland with special reference to gluing practice, which has already led to a marked improvement in the quality of the products.

THE Division of Plant Industry has been responsible for work on the control of downy mildew of tobacco by benzene vapour in covered seed beds; this has made possible the prevention of a most destructive 
disease which previously resisted all attempts at control. Considerable progress in the investigation on the control of the peach moth is reported by the Division of Economic Entomology and very favourable results have been obtained with nicotinekentonite-sulphur sprays. The same Division has been responsible for work on termite control, while the work carried out on the control of weeds has been considerably extended by reorganizing the botanical and entomological phases in one section under joint control of the chiefs of the two Divisions. The Division of Animal Health Nutrition has been responsible for investigations on pleuro-pneumonia in cattle and on the treatment of internal parasites of sheep, while its fundamental investigations on the nutrition of sheep have already led to an increase of nearly 150 per cent in the yield of wool as well as to a remarkable variation in its character. Valuable contributions to viticulture and regarding the role of organic matter in plant nutrition have been made by the Soils Division, while the Food Preservation Section has obtained promising results in investiga. tions on the storage of peaches and plums from the point of view of export to Great Britain which should decrease the wastage in export. The Radio Research Board has continued its investigations; appreciable advance in the control and eradication of prickly pear by biological methods is again reported, and a programme of fisheries research has also recently been initiated.

\section{National and International Standardization}

REALIZATION of the advantages of standardization of industrial materials and requirements has led in most of the industrially developed countries to the establishment of organizations to promote such standardization, and already a high degree of standardization has been reached in many countries. A most informative account of the work of the various national authoritative bodies engaged in this work is given in "A Survey of the Present Organization of Standardization-National and International", published by the World Power Conference. In Great Britain, the British Standards Institution is the national standardizing organization and is responsible for the determination of British standard specifications. Though the Institution has a strict rule that it does not initiate standardization but waits to be approached by a recognized outside authority such as a trade association, technical institution, or Government department, it has already issued more than 560 British Standard Specifications, exclusive of some 160 specifications for aireraft materials and components issued in co-operation with the Air Ministry.

INTERNATIONAL standardizing organizations, such as the International Federation of the National Standardizing Associations (ISA) or the International Electrotechnical Commission (IEC) have also been established. ISA, for example, federates the national standardizing organizations of nineteen countries and was founded in New York in 1926 with the object of promoting co-operation, co-ordination and interchange of information. But international co-operation, in contrast to the development of standardization along national lines, has made slow progress. It was indeed the need for further development in this direction that led the International Executive Council of the World Power Conference to initiate this inquiry, and the report has been published with the hope that it may serve as a stimulus to a greater degree of co-operation in national standardization and to a closer co-ordination of the activities of international organizations engaged in standardization, to the end that duplication and overlapping may be avoided and international standardization may be more speedily effected.

\section{Scientific Basis of Birth Control}

IN Science and Society of June-September 1937 , there appears an article on "The Scientific Basis of Birth Control" by Dr. C. V. Drysdale, president of the Malthusian League. The author remarks that the true, present-day application of the Malthusian doctrine may best be understood by reference to the affairs of an ordinary married couple. "The average young man marries when his income is sufficient to support a wife and perhaps one child, and, if that income were fixed, every additional child would mean a lowering of the family standard of existence." But, in many occupations, salaries rise with age and service, and if additional children come when there has been a sufficient rise in income, no lowering of the standard need take place. "This is the population problem as it confronts almost every middle-class couple." If children arrive at a greater rate than can be allowed for by increases of salary, then such a family is "over-populated". It amounts to this, that, in general, in civilized countries, birth-control has assisted in the preservation of the amenities and standards of living. Another aspect of birth-control is, of course, its application to what is called negative eugenics, that is, the avoidance of parenthood by persons afflicted with transmissible disease or defect. Dr. Drysdale looks forward to a future in which a planned social economy shall ensure general early marriage with reasonable family limitation. But it will be necessary to arrange that the limitation does not go too far, and the question is: How ?

\section{Fauna of the U.S.S.R.}

Some years before the Great War, the Russian Academy of Sciences launched an ambitious scheme of publishing detailed monographs on all groups of animals occurring within the Russian Empire and in neighbouring countries, under the title "Faune de la Russie et de pays limitrophes". The programme of the publication was so extensive that the first few volumes which appeared were sufficient to show the virtual impossibility of continuing the work on the same scale. The idea, however, was not abandoned, and the Academy of Sciences of the U.S.S.R. has now commenced the publication of a new "Faune de l'URSS", which aims at giving a full, but concisely written, monographic treatment mainly 